\title{
Representation of Marginalization in the Life Writing of African American Women Writers
}

\author{
Dr. Minu Kundi \\ Assistant Professor \\ Department of English \\ State Council of Educational Research and Training \\ Solan, Himachal Pradesh, India \\ minks34@gmail.com
}

\begin{abstract}
The process of imperialism and colonialism was established on the covert idea of economic and political exploitation of the underdeveloped eastern cultures by the dominant west. With the process of decolonization, the marginalized and the poor have been given a centre space alongwith the reversal of the order where those who were the object for centuries, suddenly refuse to be subjected to misrepresentation and domination, and begin to constitute their own discourses. Literature serves as a medium of honest self expression and platform to express the true self for women. American society has triply disempowered and disenfranchised African American women on the basis of race, gender and class. Many African American women writers attempt to break down traditional structures and dislocate narrative strategies in order to reexamine subject identity and to demonstrate the complexity of female experience. By writing about their lives the marginalized are valorized and their oppression turns into empowerment. Life writing helps females to explore subjectivity and to assume authorship of their own life. The
\end{abstract}


account of the life of African American women writers chronicles their frequent encounters with racism, sexism and classism as they describe the people, events and personal qualities that helped them to survive the devastating effects of their environment.

Keywords -Marginalized, African American Women, Oppression, Empowerment, Life Writing, Racism, Sexism and Classism.

The nature and approach of literary representation is a complex phenomenon. The ideological and political issues greatly influence representations and it is impossible to divorce representations from culture and society that produces them. Since times immemorial representation has been used as an ideological tool that can serve to reinforce systems of inequality and subordination, and support imperialist and neo-imperialist projects. The binary dialectic of centre/margin has been largely the creation of representation and relationship that exists between the colonial and the colonized subjects. The process of imperialism and colonialism was established on the covert idea of economic and political exploitation of the underdeveloped eastern cultures by the dominant west. In the historical past subaltern representation was completely sidelined or ignored.

The subordination of subaltern is strengthened by economic, social, racial, linguistic as well as cultural dominance. The dominant power structure controls the concepts of national identity, social reform and developmental parameters and the subaltern discourse seeks to reconsider and reexamine it with a fresh perspective. There is a need to dislodge dominant modes of representation and subvert and challenge hegemonic ideologies. The suppression of subaltern experiences into silence and absolute devaluation in national historiography is being contested and attention is being drawn towards the reconstruction of subaltern history. The mainstream 
history in current critical discourses is incorporating the marginalized, the minorities and the subcultural groups.

Subaltern denotes marginalized and oppressed people specifically struggling against hegemonic globalization. The subalterns are victims largely due to their marginal place or no place at all in the cultural history. With the process of decolonization, the marginalized and the poor have been given a centre space along with the reversal of the order where those who were the object for centuries, suddenly refuse to be subjected to misrepresentation and domination, and begin to constitute their own discourses. The subaltern studies attempt an authentic, consistent and interpretative version of history which is contradictory to the mainstream discourses or official documentation of history. The voice of subaltern which is largely silent and concealed must be disclosed and recovered. AudreLorde in her poem, "Litany for Survival," addresses the fear of speech of the marginal group and urges them to overcome it:

... and when we speak we are afraid

our words will not be heard

nor welcomed

but when we are silent

we are still afraid

So it is better to speak

remembering

we were never meant to survive.

(hooks, Talking Back 17)

Women of different class, race, national, marital status or sexual orientation groups are subjected to different degrees of patriarchal power. They are marginalized, considered to be of 
low social status and viewed as being less human than others. Literature serves as a medium of honest self expression and platform to express the true self for women. It provides positive role models which question the traditional stereotypical notions of feminine labour and capability. Women engaged in traditionally unconventional roles inspire a sense of confidence and independence. Texts written by women instill a sense of sisterhood, of oneness, of similarity of experience and existence, and helps in consciousness-raising by sensitizing women to issues of gender relations and equality.

American society has triply disempowered and disenfranchised African American women on the basis of race, gender and class. Among these three oppressions, racism is the most powerful oppression faced by African American women. It started with them being brought as slaves and continues till now. They are often been hated and degraded because of their black skin colour. She not only leads the life of black but also a woman and thus she is in a double disadvantaged position of being black and woman in white American patriarchal society. Sexism and its oppression started simultaneously with racism for black women when they were enslaved. They were made to work along with black men in plantations and were sexually abused by their white masters. Besides hard labour in the day, they became sex objects for white slave masters in the night, rampantly raped and forced to procreate a new breed of slaves which were to be sold off. Even after gaining freedom, African American women have been often raped and their modesty outraged by white men.

Though black men have always been fighting against oppression, they themselves have been tyrannical towards their own women folks. African American women have been raped beaten, abused, hated and mutilated by African American men with the same intensity as white males. African American woman is caught between racism and sexism and bears the oppression 
from both white as well as black men. She finds herself pushed to the brink, being affected by racism and crippled by sexism. African American women also suffer from classicism as they are the least privileged compared to white males, white women and African American males. They are positioned on the lowest rung of the economic and social ladder. Right from the days of slavery she is considered as the least deserving though she has been working equally alongside black males. African American women have been taking care of their children, their family and are an integral part of the African American social milieu, but she is the most ignored class; economically downtrodden and in the most vulnerable position, living the life of invisible citizens in America.

Many African American women writers attempt to break down traditional structures and dislocate narrative strategies in order to re-examine subject identity and to demonstrate the complexity of female experience. The ethos represented by the black woman can be to an extent associated with the situation of those women who occupy the margins of society in terms of race, culture and social positioning. Women writers go through a potentially challenging pilgrimage of self discovery and finally manage to define a new space and voice of their own. By writing about their lives the marginalized are valorized and their oppression turns into empowerment.

Life writing extends the field of literature, covering what used to be thought of as autobiography or biography and the different ways of inscribing the 'self' in literature. It enables a writer or reader to better understand themselves and their relationship to their world. It is a site of struggle in the representation of a life and self, and is empowering. The term life writing suggests the many different ways of writing about the subject, and can be seen as a new strategy for giving ownership and validation to the individual, a reclamation of agency, particularly to those who have been marginalized through gender, class and race. Life writing helps females to 
explore subjectivity and to assume authorship of their own life. To write and read for life is to reflect on the self and the world around us; such openness posits life writing as a relevant point of departure for a multitude of contemporary, ideological issues. Life writing raises consciousness, gives space to the uninhibited expression of the female point of view and is a vehicle for deciphering or decoding the female self. It is seen as ideologically appropriate to feminism as it is a way of telling women's story, of re-making a female story, creating a new tradition and mode of interpretation of writing for women silenced by institutionalized, monologist discourse. Life writing enacts feminism's strong exhortation to women to break the silence, to claim language and validate their unique subjective experience.

The twentieth century has been a period of intense literary activity for African American women writers. It was a time when for the first time these talented writers started to write and express their creative genius. They finally came out of the shadows of racism and sexism and created works without any inhibitions portraying their growth, struggle and accomplishment. African American women writers are acting like a mouthpiece for the existing black women in America. They have tried to declare the true reality and also created the truth in their own way, which defies existing perceptions and have universal appeal. They spread self-awareness by actively recognizing their multiple sources of oppression and they are self-empowered as they learn to rely and depend on themselves. Black women have learnt to be in action and fight for themselves because if they don't, no one else will.

For the oppressed and the exploited, finding a voice is a pertinent determinant of liberation struggle to move in the direction of freedom. In the process of learning to speak as subjects, they participate in the global struggle to end domination. Coming to voice is a gesture of resistance, an affirmation of struggle for women within oppressed groups who have contained 
so many feelings of despair, anguish and rage; who do not speak out of fear for their words will neither be welcomed nor heard. The shift from silence to speech, the idea of finding one's voice leads to self-transformation especially for women who have previously never had a public voice; women who are speaking and writing for the first time. Maya Angelou in foreword to Zora Neale Hurston's Dust Tracks on a Road writes, "There is an eerie, sometimes pathetic, oft-times beautiful urge that prevails in Black American lore, lyrics and literature. The impulse, simply put, is to tell the story ... to tell one's own story ... as one has known it, and lived it, and even died it" (vii).

Speaking becomes both a way to engage in active self-transformation and a rite of passage where one moves from being object to subject. As subject one speaks and as an object one is rendered voiceless, whose being is defined and interpreted by others. This way woman of colour begins the process of education for critical consciousness is the awareness of the need to speak and to give voice to the varied dimensions of their lives. Telling of one's personal story provides a meaningful example to those who can identify and connect. It is important for women who resist and rebel, who survive and succeed, to speak openly and honestly about their lives and the nature of their personal struggles as a means to resolve and reconcile contradictions.

Black feminism is a necessary step toward ending racism and sexism in view of the nature of gender oppression and the magnitude of resistance to racial justice by society. Feminist thinkers work to identify the specific character of their social identity both individually and collectively. With one penetrating glance they cut through layers of institutionalized racism and sexism and uncover the core of social contradictions and intimate dilemmas. Feminist struggle to end patriarchal domination should be of primary importance to women and men globally because it is that form of domination most likely to be encountered in an ongoing way in everyday life. 
Black feminism as an activist response to oppression will be needed as long as black women's subordination within intersecting oppressions of race, class, gender, sexuality, and nation persists.

Within the context of social injustice sustained by intersecting oppressions, black feminist thought as a critical social theory aims to empower African American women. Unless intersecting oppressions themselves are eliminated black women cannot be fully empowered. Black feminist thought supports broad principles of social justice that transcend black women's particular needs. Black women insist on their right to define their own reality, establish their own identities and name their history. Maria Stewart's 1831 speech advises the "daughters of Africa" to:

Awake! Arise! No longer sleep nor slumber, but distinguish yourselves.

Show forth to the world that ye are endowed with noble and exalted faculties.

(Richardson 30)

One of the most important themes in the twentieth century African American women's literature is that of growing up black and female dealing with the experiences of a black girl growing up in a hostile environment. These writers show how African American girls develop a self-resilient spirit in order to cope with adverse external environment. The account of the life of these African American women writers chronicles their frequent encounters with racism, sexism and classism as they describe the people, events and personal qualities that helped them to survive the devastating effects of their environment. Despite the triple oppression they faced as girls growing up poor in the racially segregated towns, they stress on the role models and family 
members who sustained and nurtured them and the events that contributed to their development into strong, independent young women.

Dust Tracks on a Roadwritten by Zora Neale Hurston at the age of fifty poignantly describes what it is like to grow up poor, black and female. She is one of eight children in a Negro family with small prospects of making a name for herself. Her life writing shows an energetic woman who overcomes odds to achieve liberated and rewarding life. Hurston is born in Eatonville, Florida, America's first incorporated black community; her father is a driving force in the community being a powerful preacher. Her mother dies when she is nine who inspires her children 'to jump at de sun.' The liberating force for Hurston is her love of knowledge; at the black grammar school she wins a reading contest, receiving books that ignited her imagination. She learns about real life at Joe Clarke's store, the meeting place of the men in town. After her mother's death, she moves from one place to another in search of job and education. It is her own initiative that releases her from her circumstances. She gives an account of her rise from childhood poverty in the rural South to a prominent place among the leading artists and intellectuals.

When she learns that an actress in a travelling Gilbert and Sullivan troupe is looking for a lady's maid, she approaches the woman and in her service gets marvelous education in humanity and arts. With her fighting spirit she struggles to achieve the education she feels she should have. She learns that if one wants to go to school the thing to do is to go to school, so she goes back to night high school, then to Howard University and Barnard College where she works under anthropologist Franz Boas and studies the folklore of her people in Polk County, Florida. She makes her way in research on fellowships and this leads to lifelong interest in the roots of her people. She finally becomes an outstanding anthropologist in the field of Negro folklore and 
other Negro cultures. She surveys everything from Afro-American songs to voodoo and leaves a mark on modern American music.

With hard work and natural talent Hurston faces good and bad that comes in her life in mixed portions. She feels that she is special and a different sort of person. Some of Hurston's greatest friends and confidants are the upper-class whites who are kind to her. Race consciousness is completely absent from her work as she explains that there are white niggers and black niggers, being a nigger is a matter of character rather than colour among the Negroes. She does not refer to the race riots and other atrocities of her times and there is little discussion of the issues of race and segregation. Hurston presents a more balanced view of the effects of racism on black life not because she is unaware of the seriousness of racial politics but simply because she refuses to accept the oppression of blacks as definition of her life. Her life is a dramatic adventure and she proves herself to be essentially a survivor.

I Know Why the Caged Bird Sings is published by Maya Angelou at the age of forty one. The book covers her life from childhood and describes the way she is raised in segregated rural Arkansas until the birth of her son when she is seventeen. Her focus is entirely on the inner spaces of her emotional and personal life; she recalls the sins of the past and the rituals of healing and reconciliation and thus creates a work of poignant realism and hope. Angelou inscribes her resistance to racism, sexism and poverty within the language, the imagery, the meaning of her text, confronts stereotypes with her truth-telling vision and revises perspectives. As a young girl she struggles with growing up, gains knowledge, develops a positive self-image, comes to the realization that she can control her own life and to do so must rely on her own strong intellect. She takes the chaos of her life and creates her own order. Being a lover of literature from a very young age, she appreciates it, looks to it for answers and finds it as a way of escape and anchor. 
The popularity of I Know Why the Caged Bird Sings is based upon its achieved pathos as it accomplishes a controlled poignancy in representing portrait of the artist as a young black woman. Prominent in her work is her struggle to find her own way for handling white oppression of blacks. With positive encouragement and full support of her mother Angelou confidently challenges the racist order and fights with an invincible spirit to become the first black female streetcar conductor in San Francisco at the age of fifteen. The moral stance of the book challenges its audience to confront the contradictions of life, to create positive change in one's self and then in one's community and it inspires and directs. Angelou emerges miraculously from violence, sexual abuse at the age of eight and neglects evoking awareness through the agency of memory.

Maya Angelou faces the dual injustice of racial hostility and male exploitation and in $I$ Know Why the Caged Bird Sings she describes her quest for physical and psychological survival. Angelou decides to write I Know Why the Caged Bird Sings because not enough had been written for young black girls in the United States. She wants to remind her fellow African Americans that despite the obstacles and the pain they endure, there is much love and humour to be found in the African American community. The book has a very definite appeal for young black girls as Oprah Winfrey describes in an interview with Angelou in 1993, how important the work is to her because it is the first book she has read that reflects her own experience. I Know Why the Caged Bird Sings gained popularity as a universal tale of survival and it continues to be instructive on matters of race and gender. Angelou's life is a struggle of an individual at personal level and also her fight as part of the larger marginalized section of society.

Triangular Road: A Memoir written by Paule Marshall at the age of eighty recounts powerful first-hand stories of her family and travels. She is best known as a novelist who 
explores issues of Caribbean and African American identity. Marshall focuses on the three that made up the triangular slave-trade route: the James River, the Caribbean Sea and the Atlantic Ocean. She mingles the history of each with the chronicle of her life and development as a writer. Her parents are from Barbados, a principal way station in the slave trade. They move to Brooklyn, where Marshall grew up in a close-knit West Indian community and first discovered her passion for books. She writes poignantly and at length of the slave trade that came through Richmond. She narrates a centuries-long history of human atrocities, historically locating Barbados, Virginia and Grenada in the context of the slave trade and African presence.

Marshall pays homage to Langston Hughes who with great goodwill set the extraordinary cultural tour of Europe in motion. His acts of kindness and encouragement inspire her confidence throughout her career. She provides the illuminating depth that helps establish her fame with the guidance of Langston Hughes. She portrays her imposing grandmother M' Da-duh whom she meets once when she is seven and immortalizes her in one disguise or the other in every book she writes. She gets her first lesson in the art and craft of writing by hearing her mother and friends talk in the kitchen, with their Bajan proverbs and colourful stories. She briefly tells about her first marriage, her only child and eventual divorce. Once she even cures a case of writer's block by packing away prized notebooks full of factual research finally understanding that she as a storyteller is first and foremost responsible to the story and that historical truths will come through if she crafts her tale honestly.

At the very end she pays homage to black and African creativity and comradeship. Triangular Road ends in Africa, where the journey of the ancestors of Marshall had begun. She describes her attendance at FESTAC, the Second World Festival of Black and African Arts in Lagos, Nigeria in 1977. It highlights the chaotic nature of the African American struggle for civil 
right in which she was involved as early as the 1940s. Her journey back sparks a passion to rediscover her African heritage. From her retrospective emerge important lessons that include mentor and encourage young writers, nurture and make room for one's passion, including family, friends and writing, and through a literal or spiritual return pay homage to one's heritage and lineage. Triangular Road is considered of great significance as literary text as well as socio-historical-cultural document. Marshall breaks the patriarchal imperialism of representation and celebrates womanhood. She affirms liberation from racial and gender oppression to create a literature that is political in form and in subject matter.

Coming of Age in Mississippi written by Anne Moody at the age of twenty eight tells how it was to grow up black in the era of the Jim Crow. It narrates her life from her early childhood through her involvement in the civil rights movement as a young black woman. A daughter of poor African American sharecroppers she starts working for white families at an early age of nine to support her family. She endures a tumultuous childhood bearing the triple burden of poverty, racism and discrimination; coming to fear the depths of hate as seen in the murder of Emmett Till and experiences rampant prejudice in her own life, with rising racial tensions in her community. Her involvement with the civil rights movement begins when she is a teenager, with the lynching of Emmett Till, which makes her realize the difficulties of being black in the South. Though facing much emotional distress, Moody proves to be a devoted and popular student. After attending Natchez Junior College on a basketball scholarship Moody enrolls in Tougaloo College, a historically black institution near Jackson from which she receives a bachelor's degree in 1964 .

During these years she is active in civil rights efforts in Mississippi, working with the National Association for the Advancement of Coloured People, Congress of Racial Equality and 
the Student Nonviolent Coordinating Committee. Moody is primary participant in a sit-in to desegregate Woolworth's lunch counter, along with other demonstrations in Jackson she takes part in the historic 1963 March on Washington and spearheads voter registration efforts. Being a dedicated worker, going to jail becomes a common occurrence in her life. Fearful of white retaliation she is always scared for the safety of her family. She organizes groups of teenagers to help to register black voters in Canton. Threats and violence continues against the student activists and Moody finds herself on the Ku Klux Klan's blacklist at the age of twenty three.

After graduating from Tougaloo in 1964, Moody works as the civil rights project coordinator for Cornell University in Ithaca, New York, until 1965. Eventually she becomes disenchanted with certain aspects of the civil rights movement and moves to New York where she begins to write Coming of Age in Mississippi. The book provides an eloquent and poignant account of Moody's impoverished childhood, her personal and political struggle against the pervasive racism of the Deep South and her work as civil rights activist. It received high praise as both historical and personal document and is considered of major importance in the study of the civil rights movement. Coming of Age in Mississippi is the amazing story of Anne Moody's unbreakable spirit and character throughout the first twentythree years of her life. Time and time again she speaks of unthinkable odds and conditions and how she manages to keep excelling in her aspirations, yet she ends the book with a tone of hesitation, fear, and skepticism.

In My Place written by Charlayne Hunter-Gault at the age of fifty dwells on her family history and descriptions of the southern towns where she spends her childhood. Hunter-Gault possesses the felicitousness of a woman confident in her abilities and certain of her place in history. She identifies strong teachers, good friends and a dignified father struggling as a 
chaplain in a racist army as forces that shape her and encourage her to be herself in segregated society. It is also the story of a girl who dreams of being a reporter like the comic-strip character Brenda Starr at a time when realizing such a dream is beyond the reach of most black children. She shows how her upbringing prepares her for long walk across America's racial divide and makes that achievement seem natural and inevitable. After attending a largely white school in Alaska she spends her high school years in the supportive black environment of Atlanta. Being self-confident and ambitious she gives her willingness to become a test case in the struggle for equality of education. In 1961 Charlayne Hunter-Gault at the age of nineteen becomes the first Black woman to desegregate the University of Georgia. She takes one of the first steps in a massive realignment of American society when she walks the Athens campus past a jeering mob of white students.

The 1961 desegregation of the University of Georgia by Hamilton Holmes and Charlayne Hunter is considered a defining moment in civil rights history, leading to the desegregation of other institutions of higher education in Georgia and throughout the Deep South. Holmes and Hunter had both attended all-black Turner High School in Atlanta where Holmes had been valedictorian, senior class president, and co-captain of the football team. Hunter had ranked third in her graduating class, had edited the school paper, and had been crowned Miss Turner. Nevertheless, for a year and a half university officials give a variety of reasons for denying their applications. While the court fight is being waged, the two students start their college careers at other institutions. On January 6, 1961, federal judge William Bootle hands down his finding that the two are fully qualified for immediate admission and would already have been admitted had it not been for their race and color. Even after facing agitation and riots Holmes and Hunter graduate in 1963 from the desegregated University of Georgia. 
Hunter-Gaulttells of harassment and support in those dramatic years, as well as of her growth as a journalist, her public speaking tours and even her romance with a white Southerner. She concludes with "In My Place" - the title of a stirring speech that she delivers to the 1988 graduating class at the University of Georgia. The speech includes a number of challenging thoughts about education, prejudice, marriage and the need for more black faculty members and students. Between the lines in her speech, there is her journey from reading the adventures of Brenda Starr to becoming Charlayne Hunter-Gault who travels a long way from the racist insults that first greets her on campus to become a role model for other black journalists. In My Place is a book about sit-ins, marches, court battles, and riots; a story of a young girl's entry into the civil rights movement - a movement that permanently changed the status of black people in America and altered the very structure of their society. It is a powerful act of witness to the brutal realities of segregation.The universal fight for human rights, dignity, justice, equality and freedom is not just the fight of the American Negro or the Indians, it is the fight of every ethnic and racial minority, every suppressed and exploited person, every one of the millions who daily suffer one or another of the indignities of the powerless and voiceless masses.

The twentieth century African American women writers are integral to African American women literature and have enriched American literary tradition with their own unique perspective causing a paradigm shift in African American literature. Fighting against white supremacy and their own black men's abuse, they have carved their own niche. Women writers have played a vital role in knitting together the rich vibrant yarns of African folk culture, race and tradition to produce the multi-coloured fabric of African American literature. They have brought a new change in the way of thinking and feeling in the lives of African American people, 
especially that of African American women. Their impact can be felt not only in the field of literature but in every aspect of African American life.

Today, most women in society are faced with numerous challenges and problems. Some of the major challenges that women face include gender discrimination and marginalization. Racial segregation remains deeply entrenched in housing, schooling and employment, despite important strides to desegregate U.S. society since 1970. For many African American women, racism is not something that exists in the distance; they encounter racism in everyday situations in workplaces, stores, schools, housing and daily social interaction. While they no longer live within the rigid structures of racial apartheid that characterized earlier moments in their history, they live within a culture of domination, surrounded by religious and educational institutions which reinforce the values, beliefs, and underlying assumptions of white supremacy. Despite various calls by human rights activists and non-governmental organizations to abolish and eliminate discrimination and marginalization of women, there are numerous reports that indicate that women are highly marginalized even now. Marginalization of women in the workplace has resulted into increased discrimination of women and dominance of men in the workplace.

Race, class and gender still constitute intersecting oppressions but the ways in which they are now organized to produce social injustice differ from prior eras. Women and girls are abused by their husbands and fathers, young girls are exploited by sex tourism and trafficking, girls in many countries are forced into arranged marriages at early ages. Twice as many women are illiterate as men, due to the large gap in education, girls are still less likely to get jobs and excel in the work place. Marginalization of a person often results from various stereotypes and other preconceived notions. Therefore, it is important for the society to avoid such destructive stereotypes and assumptions about its members. Oprah Winfrey states in her television talk- 
show The Oprah Winfrey Show, marginalization of women depicts serious flaws in assumptions that the society has developed towards women. She suggests that the society should take the sole responsibility to ensure that women are not marginalized within the society in any way. Gender discrimination and other maltreatments that might be directed towards women should be highly discouraged, condemned and stopped so that women can live free.

What needs to be done is what woman and girls have been striving for throughout time full equality. By equality, one means equal access to food, shelter, healthcare, education, employment and the right to life. One must be aware that gender inequality is an enormous contributor to poverty around the world, and if we want to eradicate poverty we must first end the abuse and mistreatment of woman around the world. Though girls do suffer unjustly more than boys, all children suffer when their mothers face inequality.Women and girls around the world have been striving for independence since the dawn of time, it is time we wake up and see that by marginalizing girls, we are only crippling our society. Women should be given freedom to live, to speak and to work as per their choice and men should respect them for what they are and this will end the abuse against women of all races.

Black women's struggles are part of a wider struggle for human dignity, empowerment and social justice. Anna Julia Cooper in 1893 speech to women pertinently expressed this worldview:

We take our stand on the solidarity of humanity, the oneness of life, and the unnaturalness and injustice of all special favoritisms, whether of sex, race, country, or condition.... The colored woman feels that woman's cause is one and universal; and that... not till race, color, sex, and condition are seen as accidents, 
and not the substance of life; not till the universal title of humanity

to life, liberty, and the pursuit of happiness is conceded to be inalienable to all;

not till then is woman's lesson taught and woman's cause won -

not the white woman's nor the black woman's,

not the red woman's but the cause of every man and of every woman

who has writhed silently under a mighty wrong.

(Loewenberg 330-331)

Black women intellectuals commitment to black women's empowerment advances the strikingly similar theme of the oneness of all human life. Twentieth century African American women writers have broken new grounds, created new literary canons and paved the way for twenty first century writers.

The literature of the oppressed sections of society is a reaction against the subjugation of the subaltern classes, and cultural imperialism that the dominant classes create by their dominant ideology. A shift in focus from core to periphery is one of the recent developments in literature at national and international levels. The need is to promote a literary tradition, which represents the marginal viewpoint, to incorporate them in the mainstream literary discourse. The purpose is to give realistic portrayal to the marginalized sections of society by giving them voice to assert their true concerns. 


\section{Works Cited and Consulted}

Primary Sources:

Angelou, Maya. I Know Why the Caged Bird Sings. New York: Random House, 1969. Print.

Hunter-Gault, Charlayne.In My Place. New York: Vintage, 1992. Print.

Hurston, Zora Neale. Dust Tracks on a Road. 1942. New York: Harper Perennial, 1996. Print.

Marshall, Paule. Triangular Road: A Memoir. New York: Basic Civitas, 2009. Print.

Moody, Anne. Coming of Age in Mississippi. New York: Dell, 1968. Print.

Secondary Sources:

hooks, bell. Talking Back: Thinking Feminist, Thinking Black.Boston: South End Press, 1989. Print.

Loewenberg, Bert J, and Ruth Bogin. Black Women in Nineteenth-Century American Life: Their Words, Their Thoughts, Their Feelings. University Park: Pennsylvania State UP, 1976. Print.

Richardson, Marilyn, ed. Maria W. Stewart, America's First Black Woman Political Writer: Essays and Speeches. Bloomington: Indiana UP, 1987. Print. 